\title{
Peningkatan Pelayanan PMB Berbasis Android di Politeknik Harapan Bersama Tegal
}

\section{Improving Android-Based PMB Services at the Polytechnic of Harapan Bersama Tegal}

\author{
Nurohim $^{1}$, Arfan Haqiqi Sulasmoro ${ }^{2}$, Arif Rakhman ${ }^{3}$ \\ 1,2,3 DIII Teknik Komputer, Politeknik Harapan Bersama Tegal \\ nurohim77@gmail.com ${ }^{1}$, arfan.hqq@gmail.com², cakrakirana7@gmail.com ${ }^{3}$
}

\begin{abstract}
Abstrak
Saat ini teknologi informasi dan komunikasi perkembangannya telah menyentuh kesegala Aspek kehidupan manusia, takterbantahkan lagi dalam bidang pendidikan termasuk perkembangan teknologi mobile yang menghadirkan SmatPhone dalam berbagai fungsi yang tidak saja sebagai alat komunikasi saja tetapi juga digunakan sebagai sumber informasi masa kini. Hal tersebut menciptakan kebutuhan masyarakat dilingkungan pendidikan terhadap informasi yang semakin besar dan mendorong Lembaga Pendidikan termasuk Politeknik Harapan Bersama Tegal untuk memanfaatkannya sebagai media informasi dan pendaftaran calon mahasiswa baru berbasis Android. Penelitian ini mengambil tema "Peningkatan Pelayanan PMB Berbasis Android di Politeknik Harapan Bersama Tegal" dengan tujuan membantu mahasiswa baru dalam melakukan pendaftaran menggunakan perangkat SmatPhone dan untuk membantu pihak Politeknik Harapan bersama dalam mengolah data pendaftaran. Aplikasi ini merupakan pengembangan dari aplikasi sebelumnya yang masih menggunakan berbasis Web, kemudian dikembangkan menjadi Aplikasi PMB Berbasis Android dengan melakukan pengembangan menggunakan pemrograman MIT Ai2 yang dapat berjalan disistem operasi Android.
\end{abstract}

Kata Kunci: Android, Mobile Aplikasi, MIT Ai2.

\begin{abstract}
Currently the development of information and communication technology has been approved by the aspects of human life, undeniable in the field of education including the development of mobile technology that presents SmatPhone in various functions that are not only as a means of communication, but also use today's information sources. This creates greater public demand for information on education and encourages Educational Institutions including the Harapan Bersama Tegal Polytechnic to use it as an information media and to register prospective new students based on Android. This study takes the theme "Improving Android-Based PMB Services at the Polytechnic of Harapan Bersama Tegal" with the aim of assisting new students in registering using the SmatPhone device and to assist the Polytechnic of Hope together in processing registration data. This application is a development of an application that was previously still using the Web, then developed into an Android-Based PMB Application by developing using the MIT Ai2 programming that can run on the Android operating system.
\end{abstract}

Keywords: Android, Mobile Application, MIT Ai2.

\section{Pendahuluan}

Pada Proses Penerimaan Mahasiswa Baru atau sering di sebut dengan (PMB) merupakan suatu kegiatan yang dilaksanakan oleh Perguruan Tinggi (PT) dalam upaya memperoleh mahasiswa baru. Pada Politeknik Harapan Bersama Tegal proses PMB berbagai informasi ditampilkan di website Perguruan Tinggi, khususnya pada halaman penerimaan mahasiswa baru, mulai dari informasi syarat, waktu pelaksanaan, jadwal tes, lokasi tes, dan informasi kelulusan. Berbagai jalur PMB disosialisikan juga melalui roadshow ke sekolah sekolah baik SMU, SMK, MA atau yang sederajat untuk mendapatkan calon mahasiswa baru sebanyak-banyaknya.

Penerimaan Mahasiswa Baru (PMB) adalah kegiatan wajib tahunan yang selalu dilaksanakan oleh Perguruan Tinggi (PT), baik PT Negeri (PTN) maupun PT Swasta (PTS). Berbagai informasi terkait PMB biasanya disebarkan melalui media website, termasuk informasi pendaftaran, jadwal pelaksanaan tes, lokasi tes, dan informasi kelulusan. 
Penyebaran informasi melalui web menuntut calon mahasiswa untuk selalu memantau halaman situs Web PMB untuk memeriksa ada informasi baru atau tidak. Bila calon mahasiswa tidak selalu memantau Web PMB, maka akan berisiko tidak mendapatkan informasi terbaru, khususnya bila terdapat perubahan informasi jadwal, lokasi, atau informasi kelulusan. Oleh sebab itu, perlu adanya Peningkatan Pelayanan Penerimaan Mahasiswa Baru berbasis Android berbasis Android. Aplikasi dibangun melalui tahapan analisis kebutuhan, perancangan, implementasi, dan pengujian.

Peningkatan Pelayanan PMB berbasis Android yang akan dibuat merupakan pengembangan Aplikasi sebelumnya yaitu PMB Online Berbasis Web yang dikembangkan menjadi Aplikasi PMB Online Berbasis Android yang dapat digunakan sebagai media pendaftaran mahasiswa baru. Selain itu, aplikasi tersebut juga mampu menyampaikan informasi terbaru terkait PMB secara real time yang difasilitasi dengan menu konsultasi yang interaktif melalui fasilitas media WastUp, Telephone Call, dan FB, yang didesain sedemikian rupa untuk keperluan komunikasi seputas penerimaan mahasiswa baru sehingga calon mahasiswa tidak perlu selalu mengakses web PMB untuk memperoleh informasi, karena mahasiswa dapat langsung mengaksesnya melalui Smartphone Android.

\section{Kajian Teoritik Aplikasi}

Menurut Rahman (79:2015) Aplikasi adalah software yang di transformasikan ke komputer berisi perintah perintah berfungsi..untuk menjalankan berbagai bentuk kegiatan, pekerjaan dan tugas tertentu seperti. penerapan penggunaan.. dan penambahan data.

\section{Android}

Menurut Firly (1:2018) istilah Android pada bahasa inggris berarti "Robot yang menyerupai manusia". dapat terlihat jelas pada icon Android.yang menggambarkan suatu robot berwarna hijau yang mempunyai sepasang tangan dan kaki. Sebagai suatu sistem operasi Android berfungsi sebagai penghubung (device) antara pengguna dan perangkat keras smartphone atau alat elektronik tertentu.

\section{MIT Ai2}

App Inventor 2 atau yang disingkat dengan istilah AI2 merupakan Integrated Develpment Environment (IDE) gernerasi kedua dari APP Inventor yang dikelola oleh Massachusetts Institut of Technology (MIT). AI2 masuk dalam kategori Visual Programming Berbasis Cloud yang dapat diakses dengan menggunakan internet Browser. Pemrograman AI2 menggunakan block puzzle yang disusun menjadi rangkaian kode (Gambar 1).

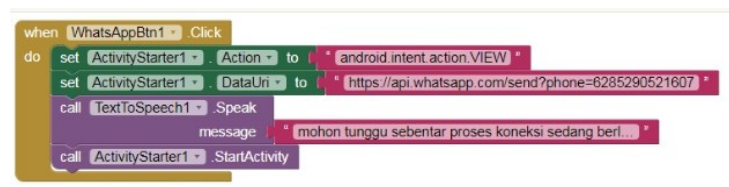

Gambar 1. Block puzzle dalam AI2

Ada tiga Bagian utama yang dimiliki AI2 adalah Component Designer, Black Editor dan Android Device yang digunakan untuk pengujian. biasanya dalam pengujian menggunakan emulator atau perangkat yang sebenarnya. Untuk perangkat sebenarnya bisa melalui jaringan wifi dan menggunakan USB. Component Designer merupakan Class dan method yang siap digunakan seperti halnya Class dan Method dalam bahasa pemrograman java, hanya saja pada AI2 disebut dengan komponen (Gambar 2.a). Komponen tersebut adalah: (1) User Interface (2) Layout (3) Media (4) Drawing \& Animation (5) Sensor (6) Social Component (7) Storage (8) Connetivity dan (9) Lego Minstroms. (Gambar 2.b). Block Editor merupakan sekumpulan blok berisi perintah yang digunakan untuk percabangan, perulangan, variable, array, serta beberapa kelas yang berfungsi seperti Public Static Class, jadi kita bisa langsung menggunakan methode tersebut tanpa perlu instansiasi (membuat objek) terlebih dahulu. Jika dilihat dari komponen yang tersedia, AI sudah cukup memadai untuk membangun aplikasi yang kompleks. 


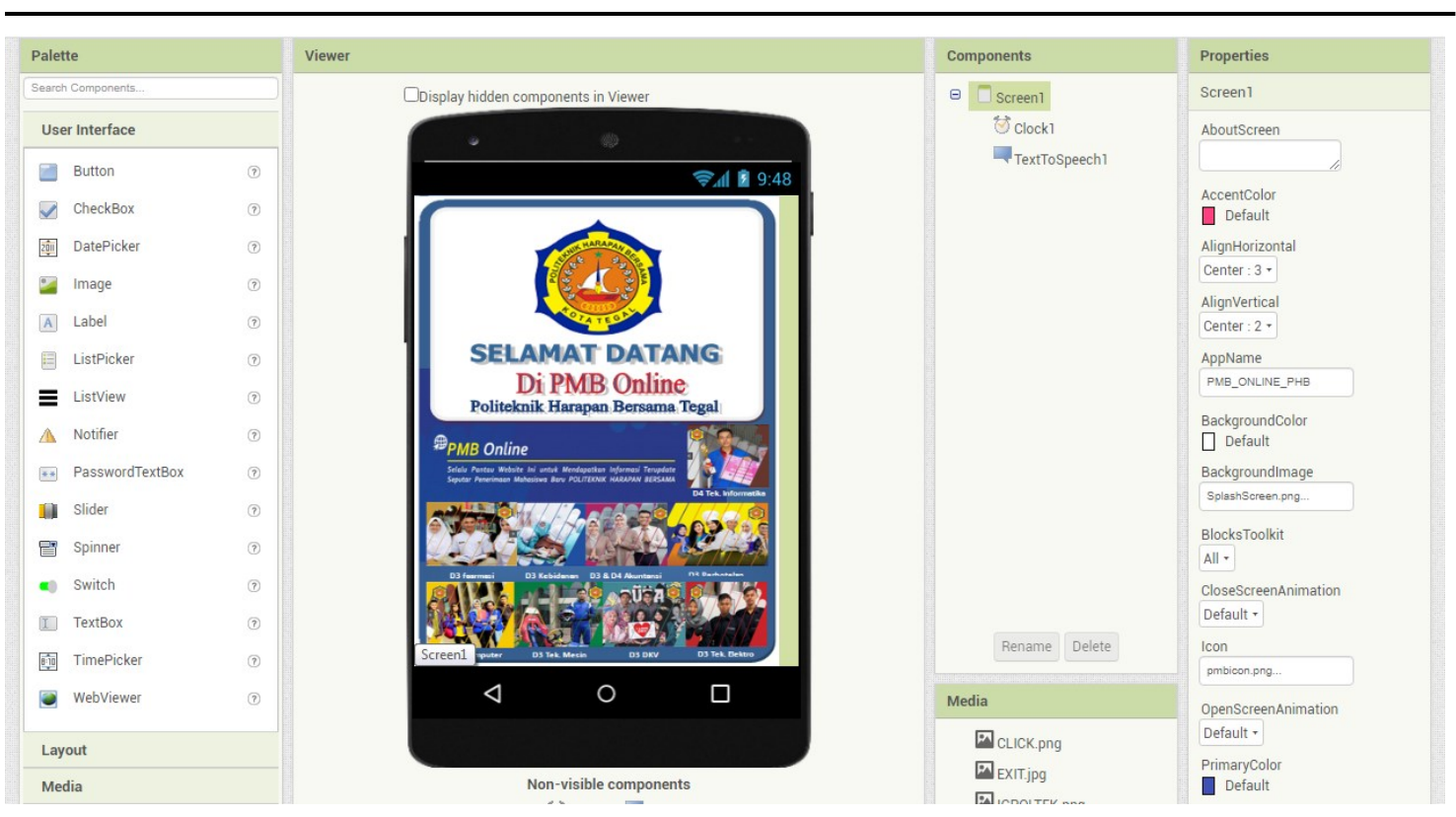

Gambar 2. Component Designer dalam AI2

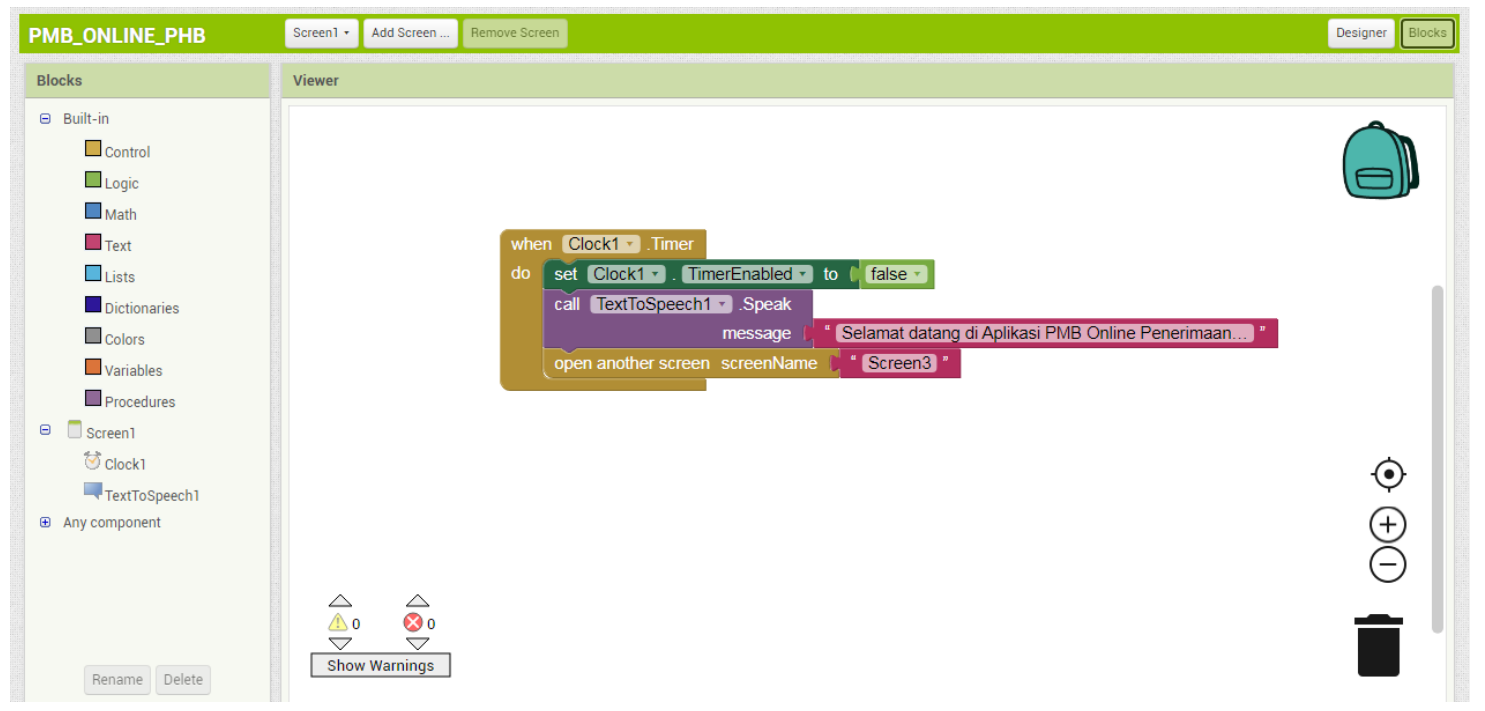

Gambar 3. Block Editor dalam $\mathrm{AI} 2$

AI2 selain mudah digunakan juga bisa mengubah persepsi orang terhadap cara membuat software (Munoz et al., 2017). Dengan menggunakan AI2 maka pemrogram pemula lebih tertarik untuk belajar membuat aplikasi(Stamatios Papadakis \& Orfanakis, 2017). Pada penelitian lain menunjukkan bahwa AI2 bisa membantu siswa sekolah dasar dan sekolah menengah yang baru belajar pemrograman dalam mempelajari konsep dasar pemrograman, mengurangi atau bahkan menghilangkan kemungkinan syntac error (S. Papadakis, Kalogiannakis, Orfanakis, \& Zaranis, 2017).

\section{Metode Penelitian}

Dalam melaksanakan penelitian melalui dua tahapan, Tahap pertama pengembangan aplikasi Penerimaan Mahasiswa Baru dan kedua pengujian berupa pengujian blackbox dan pengujian usabilitas / tingkat kemudahan pemakaian. Pada penelitian ini dikembangkan berdasarkan perkembangan rekayasa perangkat lunak dengan melalui beberapa tahapan pengumpulan data yakni observasi langsung dilapangan sampai produk siap uji dengan menggunakan Waterfall Model menurut referensi Sommerville, 2011 yaitu; 


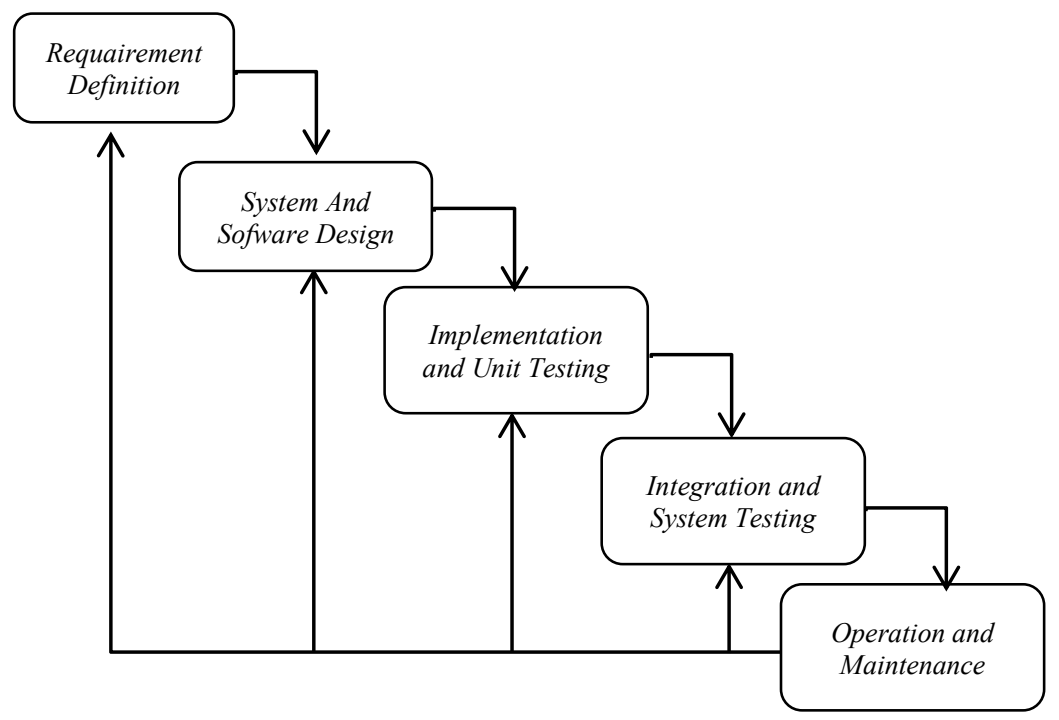

Gambar 4. Model Waterfal Sommerville (2011).

Tahapan pengembangan menggunakan model waterfall yaitu tahap pertama Requairement Definition (Tahap Analisis Persyaratan Definisi) yaitu proses penganalisaan dan pengumpulan kebutuhan sistem yang sesuai dengan kebutuhan aplikasi yang akan dibuat termasuk tingkahlaku, bagaimana penggunaanya, dan desain antar muka (interface) yang diperlukan. Pada tahap analisis ini ada dua tahap yang kami lakukan yaitu studi literatur dan studi lapangan. Studi literatur digunakan untuk mengumpulkan data-data melalui informasi yang didapat dari berbagai sumber seperti buku, jurnal maupun media internet. Sedangkan studi lapangan merupakan proses kegiatan pengumpulan data atau informasi yang diperoleh melalui sumber yang akan dijadikan sebagai pusat penelitian seperti observasi langsung dan wawancara dengan unit penerimaan mahasiswa baru politeknik harapan bersama tegal untuk mendapatkan data-data yang dibutuhkan dalam membuat aplikasi penerimaan PMB Onlne berbasis Android. Hal ini dilakukan agar aplikasi PMB yang nantinya akan dibuat tetap mengacu pada sistematik Penerimaan Mahasiswa Baru pada politeknik harapan bersama tegal tersebut.

Tahap kedua yaitu System and Software design (Tahapan Disain) yaitu tahapan disain yang dibuat menggunakan Unifed Modeling Laguage (UML) yakni dari Use Case, Activity Diagram, Sequence Diagram dan Class diagram.

Tahap ketiga Implementation and Unit System (Tahap Kode) pada tahapan ini merupakan tahapan pengkodean (coding) yang merupakan proses penerjemahan desain kedalam bahasa yang dimengerti oleh komputer dalam hal ini kami menggunakan Tool MIT App Inventor2 untuk menghasilkan produk Aplikasi Pelayanan PMB Online berbasis Android diPoliteknik Harapan Bersama tegal.

Tahap ke empat Integration and System Testing (Tahap Test)

Pada tahapan ini merupakan inti dari kegiatan penelitian ini dalam membuat sebuah aplikasi PMB online berbasis Android dari mulai Analisa, desain, pengkodingan, dilanjutkan dengan tahapan pengetesan dari semua sistem yang dipakai meliputi pengujian;

\begin{tabular}{c|l|l|c}
\multicolumn{5}{c}{ Tabel 1. Pengujian Sistem } & \multicolumn{1}{c}{ Kriteria evaluasi hasil } & \multicolumn{1}{c}{ Hasil } \\
\hline No. & \multicolumn{1}{|c|}{ Nama Pengujian } & \multicolumn{1}{c}{$\begin{array}{l}\text { Sesuai yang } \\
\text { diharapkan }\end{array}$} \\
\hline 1. & $\begin{array}{l}\text { Pengujian terhadap } \\
\text { tampilan awal } \\
\text { splashcsreen lanjut ke } \\
\text { menu PMB }\end{array}$ & $\begin{array}{l}\text { Sistem menampilkan splashscreen yang } \\
\text { dilanjutkan kemenu PMB dan layanan } \\
\text { konsultasi sesuai dengan ukuran smartphone } \\
\text { yang dipake }\end{array}$ & \\
\hline 2. & $\bullet \quad \begin{array}{l}\text { Pengujian terhadap } \\
\text { layanan konsultasi } \\
\text { melalui tool Wastup. }\end{array}$ & $\begin{array}{l}\text { Berhasil terhubung ke no WA Petugas } \\
\text { PMB yang sudah teregister di sistem. }\end{array}$ & $\begin{array}{l}\text { Sesuai yang } \\
\text { diharapkan }\end{array}$ \\
& $\begin{array}{l}\text { Pengujian Terhadap } \\
\text { Fasilitas Call Centre } \\
\text { Layanan konsultasi }\end{array}$ & $\begin{array}{l}\text { Bang sudah diset disistem } \\
\text { Berhasil masuk ke link FB PMB Politeknik }\end{array}$ & $\begin{array}{l}\text { Sesuai yang } \\
\text { diharapkan } \\
\text { Sesuai yang } \\
\text { diharapkan }\end{array}$ \\
\hline
\end{tabular}

JINITA Vol. 2, No. 2, Desember 2020 


\begin{tabular}{|c|c|c|c|}
\hline & ke FB PMB & harapan bersama tegal. & \\
\hline 3. & $\begin{array}{l}\text { Pengujian terhadap } \\
\text { halaman informasi }\end{array}$ & $\begin{array}{l}\text { Berhasil menampilkan menu informasi yang } \\
\text { sesuai dengan ukuran smartphone yang dipake } \\
\text { dengan tampilan gamabr prosedur menurun } \\
\text { fengan sekali scrol down layar. }\end{array}$ & $\begin{array}{l}\text { Sesuai yang } \\
\text { diharapkan }\end{array}$ \\
\hline 4. & $\begin{array}{l}\text { Pengujian terhadap } \\
\text { pendaftaran online }\end{array}$ & $\begin{array}{l}\text { Sisstem akan menampilkan informasi jka } \\
\text { terjadi kesalahan form yang belum diisi, } \\
\text { namun jika form sudah diisi dengan dengkap } \\
\text { maka sistem akan menampilkan pesan sukses } \\
\text { dan menampilkan username dan password } \\
\text { untuk login }\end{array}$ & $\begin{array}{l}\text { Sesuai yang } \\
\text { diharapkan }\end{array}$ \\
\hline 5. & $\begin{array}{l}\text { Pengujian Login setelah } \\
\text { mendaftar }\end{array}$ & $\begin{array}{l}\text { Setelah berhasil login dengan memasukan } \\
\text { username dan password yang benar maka akan } \\
\text { muncul halaman dasboard untuk melengkapi } \\
\text { data pendaftaran yang terdiri dari } 5 \\
\text { Step/tahapan; } \\
\text { 1. notifikasi pembayaran, untuk segera } \\
\text { melakukan pembayaran pendaftaran. } \\
\text { 2. Kelengkapan info pendaftaran, disini } \\
\text { calon mahasiswa disuruh menlengkapi } \\
\text { data pribadi lebih lengkap, } \\
\text { 3. Setelah tahap ke } 2 \text { selesai, maka ditahap } \\
\text { ke } 3 \text { adalah tahapan ferifikasi dokumen } \\
\text { oleh petugas PMB. } \\
\text { 4. Proses validasi kartu ujian beserta waktu } \\
\text { dan tanggal ujiannya. } \\
\text { 5. Pengumuman kelulusan. }\end{array}$ & $\begin{array}{l}\text { Sesuai yang } \\
\text { diharapkan }\end{array}$ \\
\hline 6. & $\begin{array}{l}\text { Pengujian Barkode } \\
\text { Aplikasi yang telah dibuat }\end{array}$ & $\begin{array}{l}\text { Aplikasi yang telah dibuat dapat di } \\
\text { identifikasikan melalui barcode smartphone } \\
\text { dan berhasil diinstal dan dioperasikan di } \\
\text { smartphone. }\end{array}$ & $\begin{array}{l}\text { Sesuai yang } \\
\text { diharapkan. }\end{array}$ \\
\hline 7. & $\begin{array}{l}\text { Pengujian Hasil APK } \\
\text { yang sudah jadi }\end{array}$ & $\begin{array}{l}\text { Apk dari program Aplikasi yang dibuat } \\
\text { berhasil diinstal di smartphone Android }\end{array}$ & $\begin{array}{l}\text { Sesuai yang } \\
\text { diharapkan. }\end{array}$ \\
\hline
\end{tabular}

Tahap ke lima Operation and Maintenance (Tahap operasi dan pemeliharaan) pada tahapan ini adala tahapan pengoperasian dan penggunaan aplikasi yang telah dibuat serta pemeliharan jika sewaktu waktu terjadi permasalahan pada saat digunakan.

\section{Hasil dan Pembahasan}

Aplikasi Peningkatan Pelayanan PMB Online Berbasis Android ini Pada saat pertamakali dijalankan harus melalui proses instalasi terlebih dahulu yaitu dengan melalui proses scaner Barcode yang telah dibuat sebelumnya setelah proses scaning barcode berhasil secara otomatis proses instalasi berjalan sampai instalasi selesai dan ketika aplikasi mulai dijalankan akan menampilkan splash screen dan masuk ke menu Awal yaitu menu PMB Online dan menu konsultasi, pada menu konsultasi ada tiga fasilitas konsultasi yang bisa dipake yaitu konsultasi dengan WhatsApp, Call Centre Sekretariat PMB, dan FaceBook PBM.

Pada menu PMB Online ini ada meu Home, Menu Pendaftaran, dan menu Log in. Pada menu Home ada beberapa informasi dari mulai Panduan Pendaftaran, Mulai daftar, informasi Pengumuman bagi reguler pagi dan reguler malam termasuk informasi biaya kuliah, serta informasi semua program studi yang ada di Politeknik Harapan Bersama Tegal.

Pada tahap awal ketika calon mahasiswa mau mendaftar, calon mahasiswa harus klik menu "Pendaftaran" dan pilih menu "Daftar". Setelah klik menu daftar calon mahasiswa diharuskan mengisi form pendaftran sampai selesai sehingga calon mahasiswa akan mendapatkan no registrasi dan pasword untuk proses selanjutnya yaitu melakukan Login.

Flowchart Aplikasi Peningkatan Pelayanan PMB Online Berbasis Android tertera pada Gambar 2 


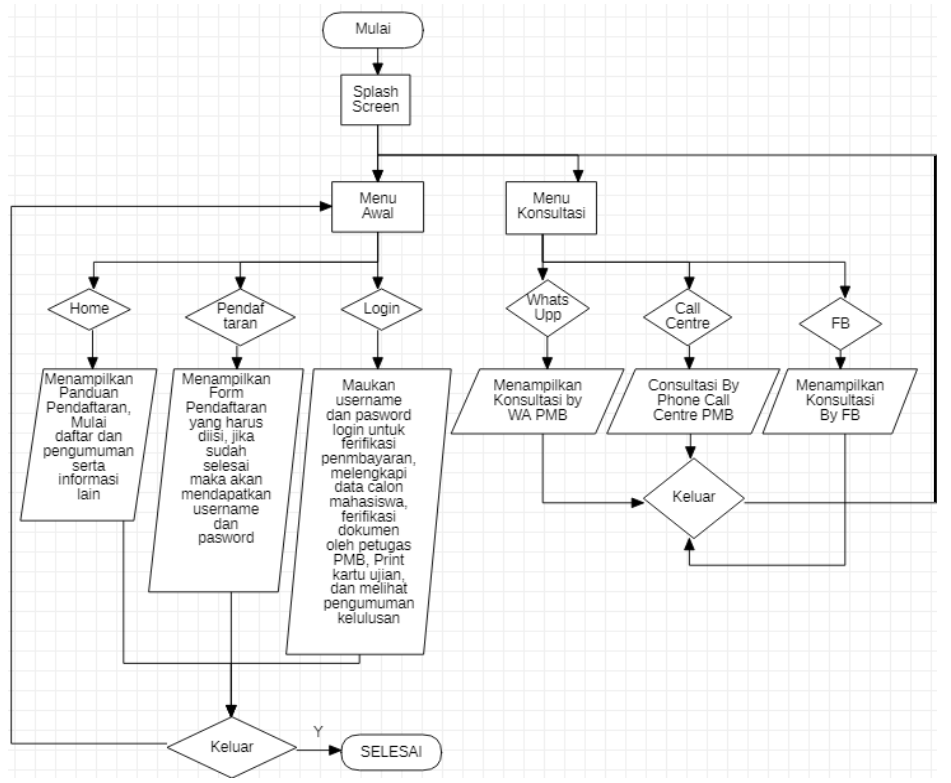

Gambar 5. Flowchart Sistem Aplikasi Peningkatan Pelayanan PMB Online Berbasis Android.

Untuk memudahkan pengembang Aplikasi peningkatan pelayanan PMB Online berbasis Android dalam merancang menggunakan Use Case Diagram karena pada Use Case Diagram terlihat jelas dan aktivitas yang dilakukan pada Pelayanan Peningkatan PMB Online Berbasis Android, sebagaimana terlihat pada Gambar 3 dibawah ini.

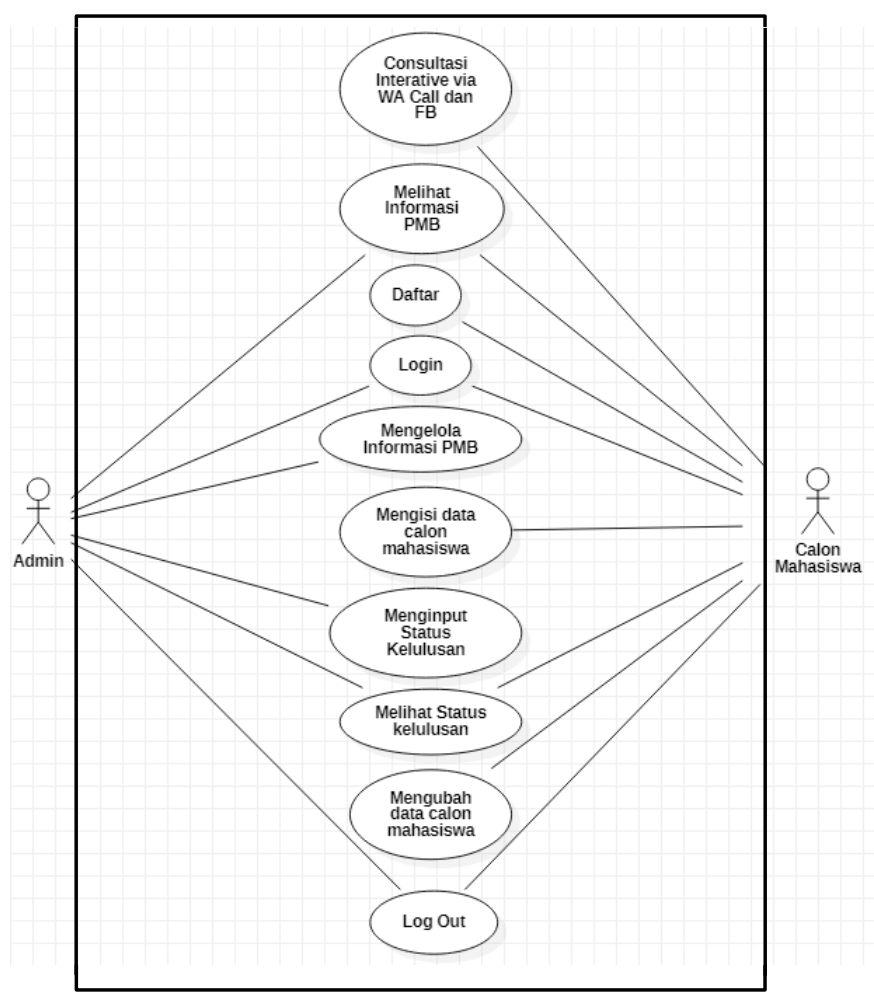

Gambar 6. Diaagram Use case Aplikasi Peningkatan Pelayanan PMB Online Berbasis Android

Tampilan Pertama kali pada saat aplikasi dijalankan adalah menampilkan SplashScreen sebagai tampilan awal yang durasinya hanya 5 detik saja, yang Layoutnya tertera pada Gambar 7 dibawah ini. 

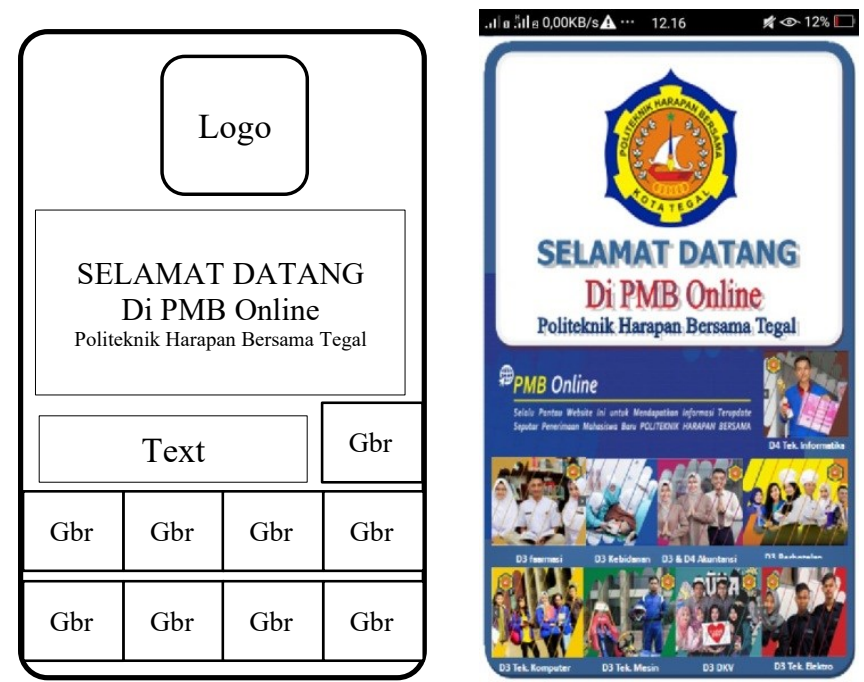

Gambar 7. Tampilan Layout Splash Screen dan implementasinya

Pada tampilan menu awal terdapat beberapa pilihan menu seperti menu PMB Online, menu WhastApp, menu Call Centre, Menu FaceBook, menu saran dan masukan, Menu Exit. Adapun tampilan Layout menu Awal tertera pada Gambar 7. Tampilan Layout menu awal merupakan tampilan yang pertamakali muncul setelah splashscreen pada aplikasi PMB Online berbasis Android.
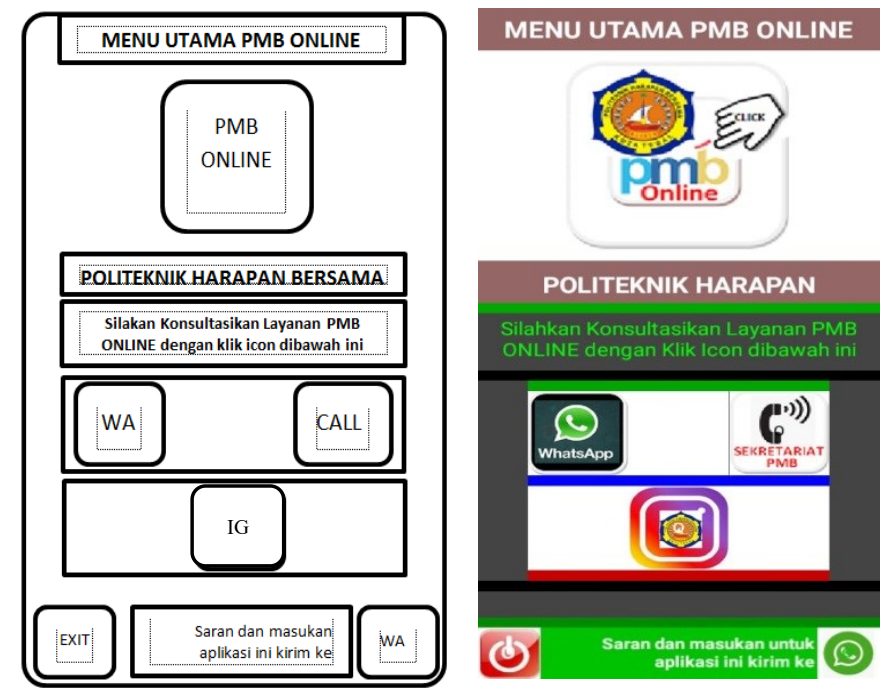

Gambar 8. Tampilan Layout Menu utama Awal dan Implementasinya

Pada Gambar 8 diatas akan kita lakukan proses pengujian dari menu WhastApp, Menu Call, dan Menu IG PMB, seperti pada tampilan Gambar 9 di bawah ini adalah hasil pengujian dari ke 3 menu tersebut. 

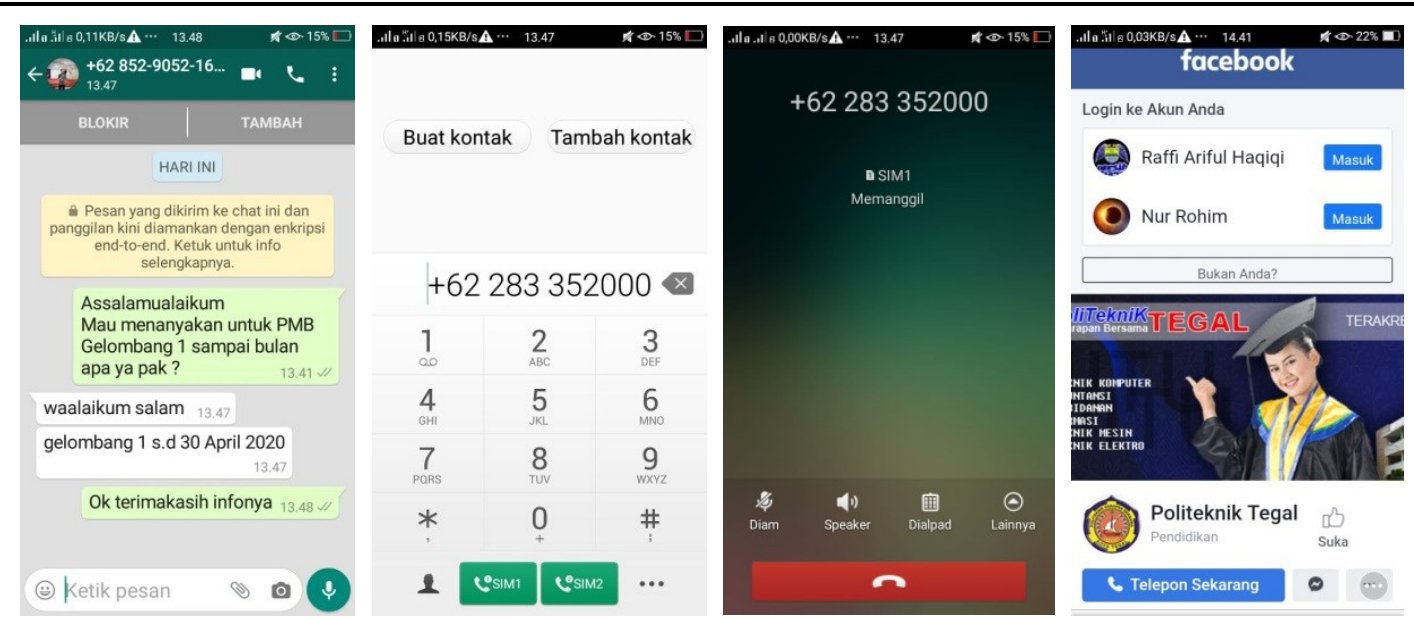

Gambar 9. Tanpilan Pengujian terhadap fasilitas menu WhastApp, Call Centre, dan link FB PMB.

Demikian hasil pengujian terhadap menu konsultasi diatas. Selanjutnya kita akan melakukan proses pengujian terhadap menu PMB yaitu dengan mengklik Button PMB Online Maka akan menampilkan halaman menu utama yang terdiri dari menu Home, Menu Pendaftaran, dan Menu Login. Seperti pada tampilan Gambar 10 dibawah ini, dimana pada menu home menampilkan informasi Panduan Pendaftaran, informasi mulai mendaftar, informasi Pengumuman bagi reguler pagi dan pengumuman bagi reguler malam dan termasuk informasi biaya perkuliahan dari masing-masing program studi yang ada di politeknik harapan bersama Tegal.

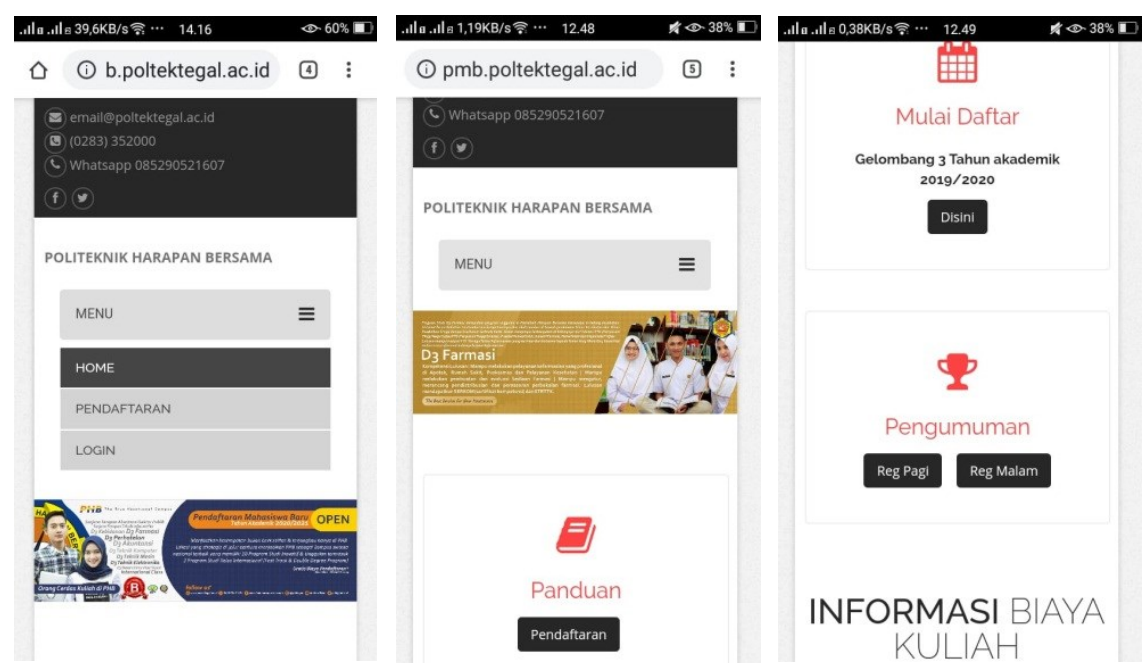

Gambar 10. Hasil tampilan dari button PMB Online

Pengujian tergadap menu pendaftaran yaitu dengan mengklik menu Pendaaftaran sehingga akan muncul form pendaftaran yang harus diisi, seperti pada tampilan Gambar 11 dibawah ini. 


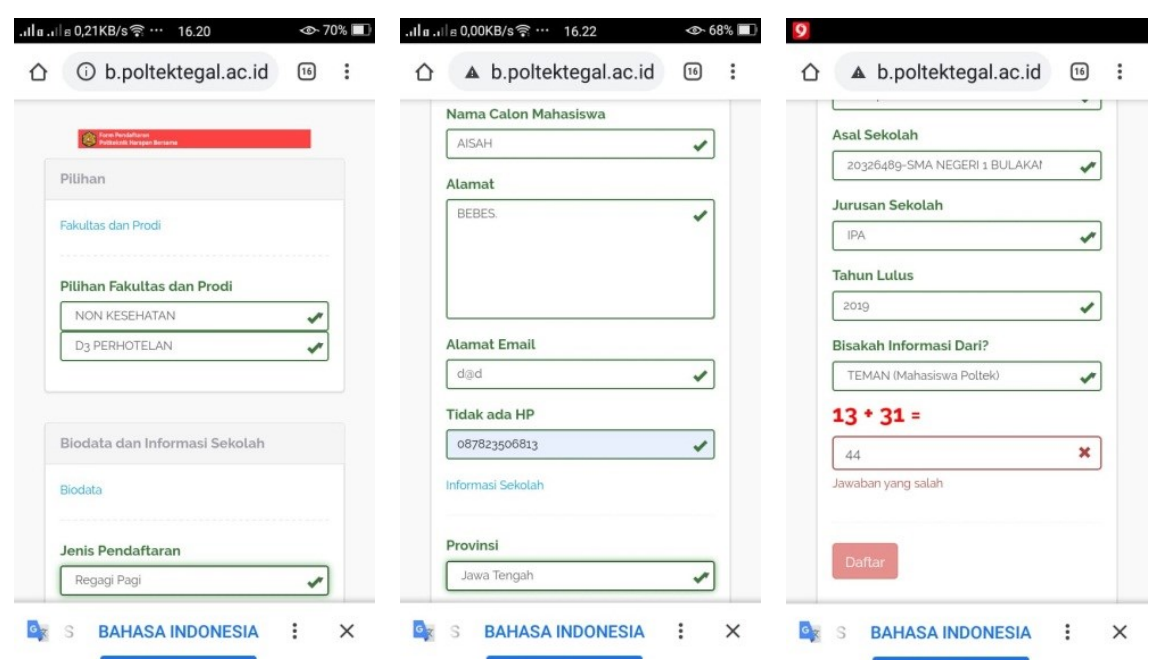

Gambar 11. Hasil Tampilan form isian Pendaftaran

Setelah semua terisi maka langkah selanjutnya mengisi penjumlahan angka yang ditampilkan secara random kemudian klik menu daftar sehingga si pendaftar akan mendapatkan no Pendaftaran beserta Username dan Password seperti ditampilkan pada gambar 12 dibawah ini.

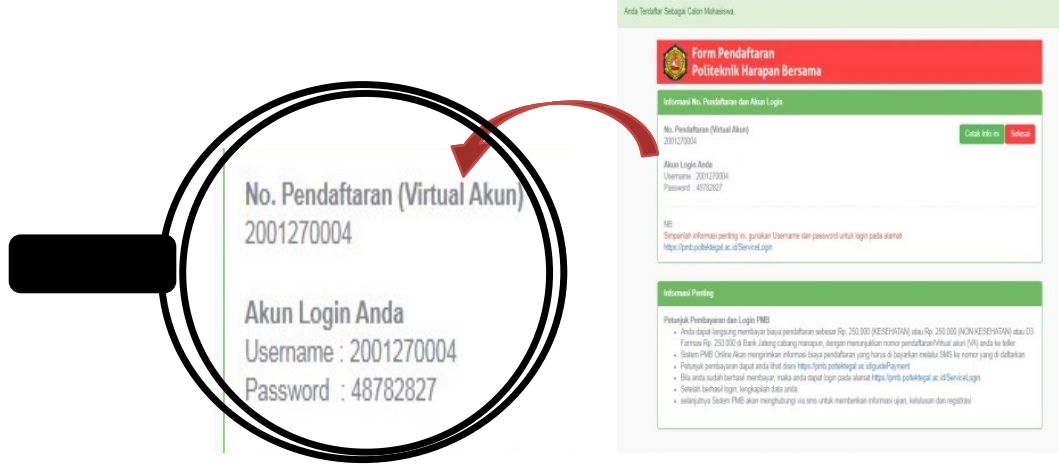

Gambar 12. Tampilan setelah mengisi form pendaftaran

Setelah mendapatkan No pendaftaran beserta Username dan Password maka langkah selanjutnya adalah masuk atau klik menu Login dan isikan username dan password yang tadi didapatkan, selanjutnya klik Sign in, seperti pada tampilan Gambar 13. Dibawah ini.

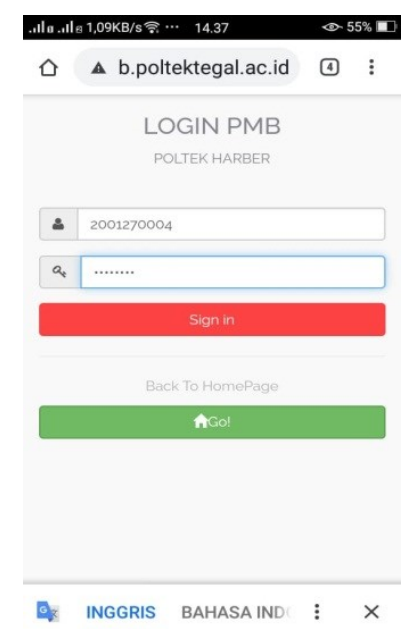

Gambar 13.. Tampilan Menu Log in Calon mahasiswa 
Setelah mahasiswa melakukan proses Log in maka alon mahasiswa harus melengkapi data calon mahasiswa baru, seperi pada tampilan Gambar 14 dibawah ini;

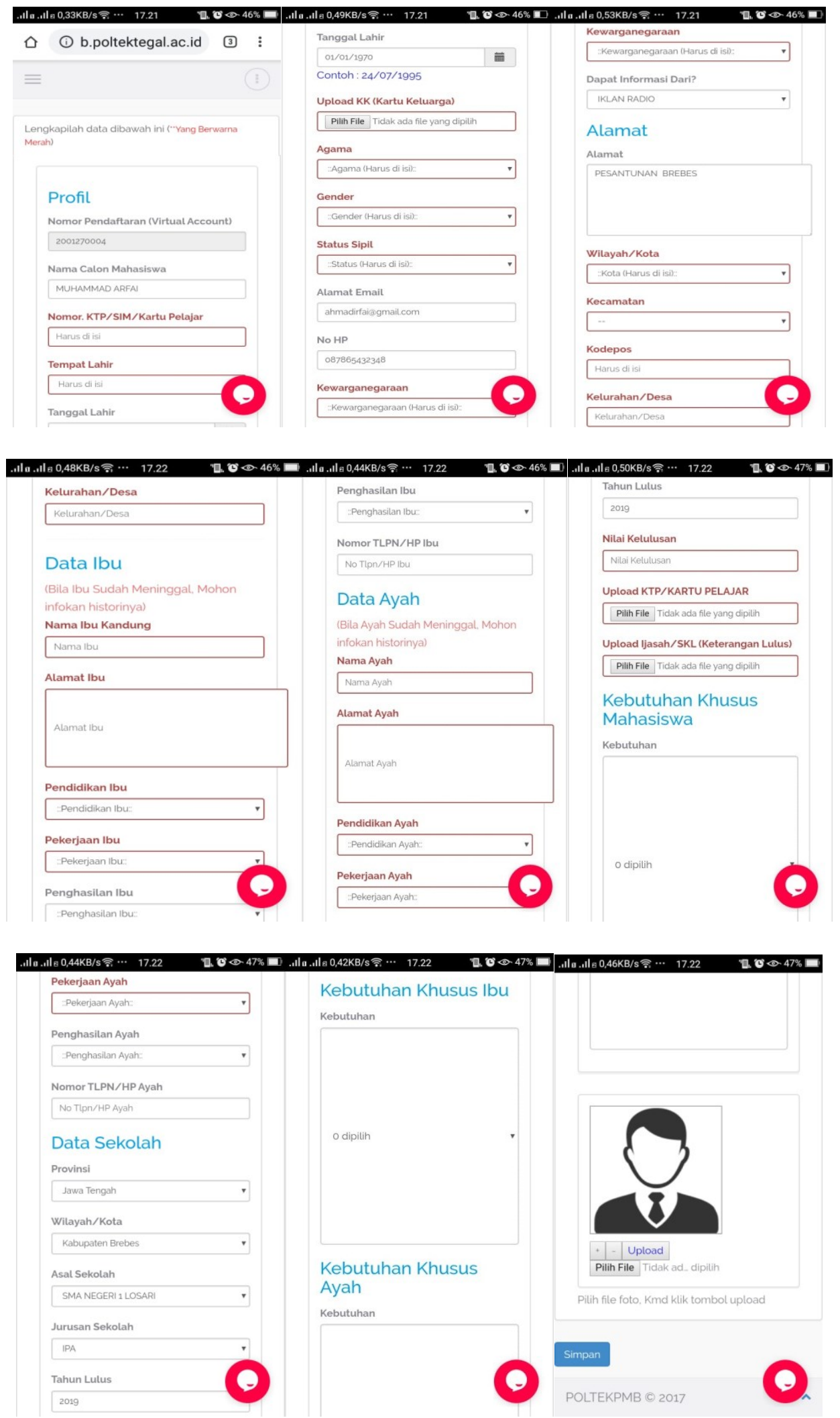

Gambar 14. Form untuk melengkapi data calon mahasiswa baru 
Setelah selesai melengkapi data calon mahasiswa baru dan sudah disimpan maka langkah selanjutnya masuk ke menu dasboar yang akan ditampilkan seperti pada Gambar 15 dibawah ini;
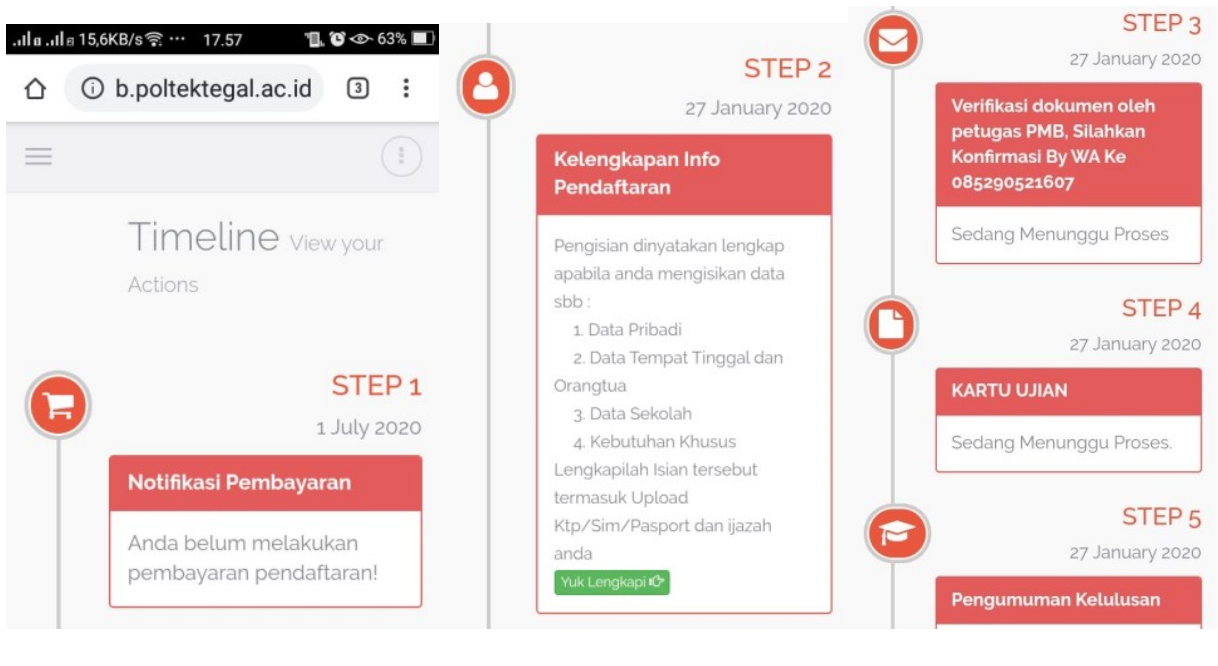

Gambar 15. Tampilan Form Dasboard

Pada Gambar 15 diatas ada 5 step tahapan /langkah yang harus diselesaikan dari step 1 yaitu mahasiswa harus sudah melaksanakan proses pembayaran via bank yang sudah ditunjuk, sehingga bisa dilanjutkan step 2 nya yaitu melengkapi biodata lengkap calon mahasiswa yang meliputi ; data pribadi, data tempat tinggal dan orang tua, Data sekolah, kebutuhan khusus. Setelah selesi di tahap 2 kemudian dilanjutkan step 3 yaitu proses menunggu Verifikasi dokumen oleh petugas PMB yang biasanya dikonfirmasi via WA. Selanjutnya step 4 setelah proses verifikasi oleh petugas PMB selesai maka akan muncul/diterbitkan Kartu Ujian Calon Mahasiswa Baru yang bisa di cetak oleh calon mahasiswa. Kemudian langkah ke 5 yaitu melihat hasil pengumuman kelulusan calon mahasiswa baru.

\section{Kesimpulan}

Aplikasi Peningkatan Pelayanan PMB Online Berbasis Android untuk keperluan penerimaan calon mahasiswa baru di politeknik harapan bersama tegal dapat diterapkan sebagai media atau sarana pendaftaran mahasiswa baru berbasis Android dengan baik dan lancar. Aplikasi PMB Online berbasis Web sebelumnya dapat dikembangkan mejadi Aplikasi PMB Online Berbasis Android dengan menggunakan Integrated developmen environment (IDE) MIT Ai2 dan berjalan dengan baik di semua smartphone. Aplikasi PMB Online Berbasis Android dapat memudahkan calon mahasiswa baru dalam melakukan konsultasi dan tanya jawab secara interaktif dengan team Panaitia PMB secara langsung dengan fasilitas Tool menu konsultasi yang disediakan diaplikasi.

\section{Daftar Pustaka}

[1] S. Santoso, D. Saputra, and D. Pebriana, "Aplikasi Penerimaan Siswa Baru Berbasis Mobile Web Studi Kasus: SMA Citra Islami,” SESINDO 2013, vol. 2013, 2013.

[2] K. Y. Palilingan, A. A. Sinsuw, and X. B. Najoan, "Registrasi Calon Siswa Baru Berbasis Mobile Android di Sekolah Menengah Atas Negeri 9 Manado," E-J. Tek. ELEKTRO DAN Komput., vol. 3, no. 3, pp. 26-30,2014.

[3] T. Ramadhan and V. G. Utomo, "Rancang Bangun Aplikasi Mobile Untuk Notifikasi Jadwal Kuliah Berbasis Android (Studi Kasus: STMIK Provisi Semarang)," J. Teknol. Inf. Dan Komun., vol. 5, no. 2, pp. 47-55, 2014.

[4] P. Petrus, S. Suyoto, and T. Suselo, "Analisis Dan Desain Aplikasi Pendaftaran Mahasiswa Baru Berbasis SMS, Studi Kasus: Asmi Santa Maria Yogyakarta,” J. Buana Inform., vol. 2, no. 1, 2011.

[5] J. S. Balasaheb, S. B. Sitaram, W. V. Khushalrao, V. N. Ashok, and M. P. Bhausaheb, "Web Based College Admission System," IJEDR, 2014.

[6] Erliyah Nurul Jannah, Dwi Khusnul Bayturrohman, Endang Kurniawan, "Pengembangan Aplikasi Penerimaan Mahasiswa Baru Berbasis Android dilengkapi dengan fitur push Notification,”JNTETI, vol 6, no.4, November 2017 
[7] E.S. Wihidayat, "Pengembangan Aplikasi Android Menggunakan Integrated Development Environment(ide) App Inventor-2” Jurnal Ilmiyah Edutic, vol 4, no.1, November 2017

[8] Munoz, R., Barcelos, T., Villarroel, R., Becerra, C., Noel, R., \& Ponce, F. (2017). Using app inventor to change perceptions about software engineering. Proceedings - International Conference of the Chilean Computer Science Society, SCCC. 